\title{
Development of diversified product using waste cotton and wool fibres
}

See end of the paper for authors' affiliations

\section{REENA ROY}

Department of Textile and Apparel

Designing, College of Home

Science, Maharana Pratap

University of Agriculture and

Technology, UDAIPUR

(RAJASTHAN) INDIA

Email : royhscreena154@gmail.

com
ABSTRACT : Cotton is a cellulosic fibre obtained from plants and wool is also fibre which obtained from animal hair. A diversified product refers to the produce the large variety of manufactured products from raw material such as waste cotton rags and wool fibres. Cotton and wool waste is worthless and also pollutes the environment. Waste cotton rags and wool fibres can use in developing diversified products. The diversified products made by waste cotton and wool are decorative and functional in nature. Decorative products include photo frame, greeting cards, flower pots, lamp lighting, flowers, mask, wall hanging, while functional articles includes book holder, guest book, tea coaster, pen holder etc.present study mainly focused on the pre consumer waste, post-consumer waste, waste clothes management, how to develop the different diversified products by using waste cotton and wool pieces, benefits of these products to consumers and environment.The present study is more relevant and beneficial because now-adays cotton industry discharges different types of waste across the state and country which can be manage by developing decorative and functional diversified products in econ friendly manner. Present study suggests an innovative way of waste clothes management which helps in converting the waste material into different useful and decorative products using waste cotton rags and wool fibres.

KEY WORDS: Diversified products, Pre consumer waste, Wool fibre, Decorative articles

- HOW TO CITE THIS PAPER : Roy, Reena, Dashora, Shikha and Babel, Sudha (2016). Development of diversified product using waste cotton and wool fibres. Asian J. Home Sci., 11 (1) : 276-280, DOI: 10.15740/HAS/AJHS/11.1/276-280. 